\title{
Mar'it Ozen: From the Ancient Water-mill to Automated Electronic Devices
}

\author{
Joshua Kulp and Jason Rogoff
}

In the fall of 2017, students from the Jewish Theological Seminary Rabbinical School and the Conservative Yeshiva studied Tractate Shabbat. This article is an outgrowth of our hevruta and the shiurim we delivered on the subject. We will demonstrate how academic Talmud study helps us gain a deeper understanding of medieval interpretations of the Talmud and modern halakhic rulings.

When reflecting on the differences between a prayer service at a typical Orthodox synagogue and one at a typical Conservative synagogue, the first that usually comes to mind is related to the role of women. Conservative synagogues do not have a mehitzah, and for the most part women participate in the same roles as do men. Many Conservative synagogues shift the liturgy in order to reflect egalitarian ideals. But there is another difference that equally affects the experience undergone in these prayer services, one that almost uniformly distinguishes between Orthodox and non-Orthodox synagogues - the use of a microphone. ${ }^{1}$ This paper is not a halakhic responsum on the use of a microphone on Shabbat. Such a discussion would have to discuss all facets of its use, including the use of electricity. Rather, we focus here on two Talmudic prohibitions that become intertwined in the Yerushalmi and Bavli and then separated again in late responsa literature. The first is the notion that one's vessels must rest on Shabbat. This is known in the Bavli as "the resting of vessels." The second is the prohibition of making loud noises on Shabbat. We will show how literary considerations in the Bavli impacted post-Talmudic halakhah ${ }^{2}$ and then trace how these two issues play out among several modern halakhic authorities. This case is an excellent example of how the modern academic approach to the

1 In fact, there was a brief period in which some Orthodox rabbis allowed and even used a microphone in the synagogue. See Louis Bernstein, "The Emergence of the English Speaking Orthodox Rabbinate" (Ph.D. diss., Yeshiva University, 1977), 82-85. Our thanks to Professor Jonathan Sarna and Rabbi Zev Eleff for their help in locating this reference.

2 See Ethan Tucker's discussion of this phenomenon in his chapter in our book, Reconstructing the Talmud, and ed. (New York: Hadar Press, 2016), 149-170. 
study of Talmud can potentially impact our adaptation of ancient halakhah into the rapidly changing technology that so characterizes our society.

\section{The Resting of Vessels}

The first chapter of Mishnah Shabbat contains a well-known debate between Beit Shammai and Beit Hillel concerning whether it is permissible to begin a process of work on erev Shabbat (Friday afternoon, before dark) that will continue on Shabbat. In the Mishnah and in the parallel in the Tosefta there are multiple points of disagreement between the two houses (in each of these cases Beit Shammai prohibits and Beit Hillel permits) and at least two points of agreement. In our Reconstructing the Talmud: Volume II, we explain the overall reasoning behind these debates. ${ }^{3}$ Here we will only briefly outline our conclusions. According to Beit Shammai, one is not allowed to begin processing a material on erev Shabbat if that material will be ready for use on Shabbat and could in theory be used on Shabbat. An example is soaking ink. It does not matter to Beit Shammai that the person is not actively performing work with his own hands on Shabbat, nor does it matter that the object probably will not be used (it is forbidden to use ink on Shabbat). In contrast, Beit Hillel says that as long as one is not performing the work with his own hands on Shabbat, and he will likely not use the item on Shabbat (such as ink), it is permitted to set the process in motion before Shabbat.

Following a debate between the two houses and a citation of midrashic support for both positions, the Tosefta continues with another source which seems to relate in general to the same topic: the beginning of processes before Shabbat that will continue on Shabbat. But this time neither house is mentioned, nor does there seem to be any debate about the issue.

תוספתא שבת א:כג

פותקין מים לגנה בערב שבת עם חשיכה, והיא שותה והולכת בשבת.

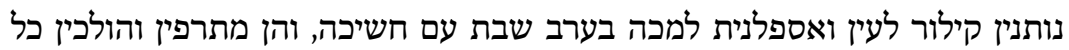

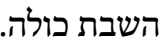
נותנין גפרית תחת הכלים בערב שבת עם חשיכה, והן מתגפרין והולכין בשבת. נותנין מגמר על גבי גחלים בערב שבת שת עם שם חשת עם חשכה. ואין נותנין חטים לרחים של מים אלא כדי שייטחנו.

3 Joshua Kulp and Jason Rogoff, Reconstructing the Talmud: Volume II (New York: Hadar Press, 2019), 83-124. 


\section{t. Šabb. 1:23}

One may conduct water into a garden on Friday afternoon just before dark, and it may go on being filled the whole day.

And one may place an eye salve on the eye and a plaster on a wound on Friday afternoon just before dark and it will continue healing all day.

And one may place sulfur under [silver] vessels on Friday afternoon just before dark and it may continue making sulfurous odor all day;

And one may place incense on top of coals on Friday afternoon just before dark.

But one may not place wheat in a water-mill unless it can be ground [when it is still day].

There are essentially two parts to this baraita: The first part lists processes that may be set in motion before Shabbat and the second part lists one process which is forbidden even if set up before Shabbat. In our aforementioned book, we explain that Beit Shammai would allow the activities in the first section for they do not consist of processing material. The person is not processing the water, sulfur, salve, bandage, or incense. Rather he is starting a process involving one substance, water, sulfur, salve, bandage, or incense, that aids something else, garden, vessel, eye, wound, or clothes. Since he is not processing an item on Shabbat, even Beit Shammai would permit these activities. Put another way, unlike the example of processing dyes, most of these substances are used up in the process which they are undergoing, much in the same way that oil is used up by a lamp, and wood is used up by a burning fire; both activities which Beit Shammai permits setting in motion on Friday right before Shabbat. The second half of the baraita can be explained according to our general reasoning as a point where Beit Hillel agrees with Beit Shammai. When it comes to grinding wheat, an item is being processed, and since this is a food item that potentially could be eaten on Shabbat, ${ }^{4}$ even Beit Hillel would agree that it is prohibited.

\section{Yerushalmi}

Since in this article we focus primarily on the placing of wheat into a water-mill and the justification for this prohibition, we will quote here only the section of the Yerushalmi relevant for the issue at hand.

4 Ground wheat can be chewed, see t. Ber. 4:6. 
ירושלמי שבת א:ד (ג, ד ד דים

אין נותנין חיטים לריחים של מים אלא כים כדי שיטחנו כל צורכן מבעוד יום.

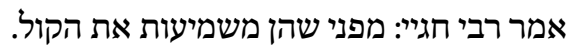

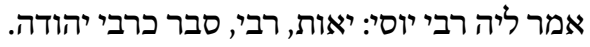

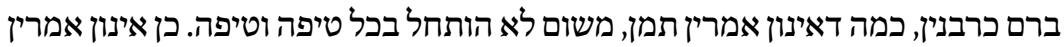

הכא, משום לא הותחל בכל חיאינון אמריזת וחיטה. משת.

אמר רבי יוסי בי רבי בון: מפני שהוא שכו שכח ותוקע את היתד.

\section{y. Šabb. 1:4, 3d}

One may not place wheat in a water-mill unless it can be fully ground when it is still day.

R. Haggai says: Because it makes noise.

R. Yose said to him: What you say is true, Rabbi, if you hold like R. Yehudah. But according to the other rabbis, it is like we said there, for each drop has not yet begun [to drip into the lamp]. So too we say here that [the grinding] has not begun with each piece of wheat.

R. Yose son of R. Bun said: Because he will forget and he will put in the peg.

Following the quote of the baraita, we have three different explanations from Amoraim from Eretz Yisrael as to why it is prohibited to place wheat into a water-mill on erev Shabbat. R. Haggai explains that the problem with grinding wheat on Shabbat is that it will make noise, and thus is prohibited even if the process is set in motion on erev Shabbat. The prohibition of creating a noise on Shabbat is well-documented in both Talmudim. R. Haggai's explanation reflects the general ban on noise-making found in Eretz Yisraeli texts. Activities such as ringing a bell, clapping, shaking a rattle, and knocking on a door are prohibited because they are a disruption of the tranquil atmosphere of Shabbat. ${ }^{5}$ In light of the intention of this prohibition, it does not matter that the process is set in motion before Shabbat. The noise will be made on Shabbat, and therefore it is prohibited. This concern will be the focus of our analysis of the Bavli and medieval commentators below. The Yerushalmi contains two other Amoraic explanations of the water-mill prohibition, neither of which appears in the Bavli. These explanations are not germane to the subject of this paper. However, it is worth noting that the Yerushalmi does not entertain the possibility that Beit Hillel would permit putting wheat in a water-mill. Nor does the

5 See m. Beșah 5:2; t. Šabb. 13:15-17; y. Beșah 5:2, 63a; b. 'Erub. 104a. See Avraham Goldberg, Commentary of Mishnah Eruvin (Jerusalem: Magnes Press, 1986), 312 n. 55. 
Yerushalmi seem to struggle as to why Beit Hillel would prohibit this action, but permit the other actions which are the subject of the Mishnah and the earlier section of the Tosefta. While there is some dispute as to why this particular action is prohibited, it is abundantly clear in the Yerushalmi that it is prohibited by both Houses.

\section{Bavli}

The Bavli begins with the Toseftan baraita and then offers the same explanation that appears in the Yerushalmi.

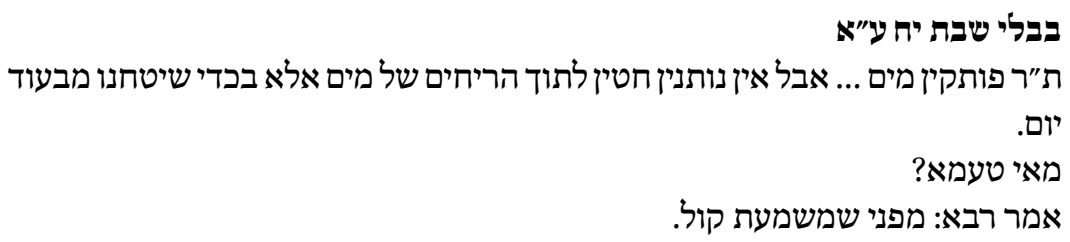

\section{b. Šabb. $18 a$}

Our rabbis taught: One may conduct water ... But one may not place wheat in a water-mill unless it can be ground when it is still day. What is the reason? Rava ${ }^{6}$ answered: Because it makes a noise.

Up until this point, the sugyot in the two Talmudim are identical, and both relatively simple to explain. In contrast, the structure of the continuation of the sugya in the Bavli is exceedingly difficult, it contains some strained points, and as we shall see, it is the source of the differences in the halakhic rulings of the Rishonim.

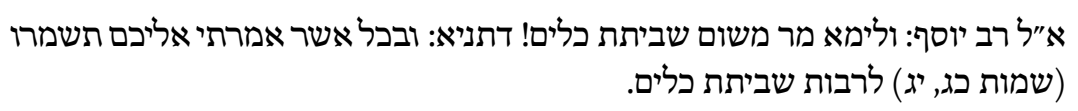

6 All textual witnesses of our sugya, including genizah fragments, manuscripts, and the majority of printed editions, attribute this statement to Rava. The Vilna printed edition, influenced by the emendation of R. Solomon Luria (16th century), reads Rabbah. The early medieval commentators also attribute this statement to Rabbah because the sugya presents his statement as a direct response to R. Yosef, his colleague. In our analysis below of the medieval and modern halakhic authorities we will attribute the statement to Rabbah in order to remain consistent with their attribution. On the difficulty of determining the attribution of statements to Rava/Rabbah see Shamma Friedman, "Orthography of the Names Rabbah and Rava," Sinai 110 (1992): 140-164. 
אלא אמר רב יוסף: משום שביתת כלים. והשתא דאמרת לב"ה אית להו שביתת כלים דאורייתא, גפרית ומוגמר מאי טעמא שרו? ....

והשתא דאמר רב אושעיא אמר רב אסי: מאן תנא שביתת כלים דאורייתא? ב"ש היא

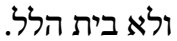
לב"ש בין קעביד מעשה בין דלא קעביד מעשה אסור, לבית הלל אע"ג דקעביד מעשה

R. Yosef said to him: Let the master say it is on account of the resting of vessels? For it was taught: And in everything that I have said to you take heed (Exodus 23:13) this includes the resting of vessels.

Rather R. Yosef said: it is on account of the resting of vessels.

Now that you say that Beit Hillel holds that the resting of vessels is a biblical commandment, why did they permit sulfur and incense? ...

Now, however, that R. Oshaya said in the name of R. Assi: Which tanna [holds that] the resting of vessels is a biblical commandment? It is Beit Shammai.

Then according to Beit Shammai, whether it [the utensil] performs an action or not, it is forbidden, while in the opinion of Beit Hillel even if it performs an action it is permitted.

R. Yosef asks why Rava did not explain that the prohibition was "because of the resting of vessels." $R$. Yosef then cites a midrashic baraita supporting the idea that one is commanded to allow one's vessels to "rest" on Shabbat. ${ }^{7} \mathrm{He}$ then replaces Rava's explanation as to the water-mill prohibition with his own reasoning, because of "resting of vessels" (shevitat keilim).

According to the arrangement of the material in the sugya, which assumes that the baraita is agreed upon by both Houses, R. Yosef is supposed to be explaining the baraita such that it will accord with both Beit Hillel and Beit Shammai. R. Yosef seems to posit that Beit Hillel prohibits using a water-mill not because of a specific problem with this particular activity but due to a larger category of prohibitions which he terms "the resting of vessels on Shabbat." This is, we should note, the earliest appearance in rabbinic literature of this broad term. The problem is that the notion that Beit Hillel agrees with Beit Shammai that one's "vessels must rest on Shabbat" contradicts Beit Hillel's generally permissive position as reflected in Tannaitic sources. How can Beit Hillel

7 This baraita is not found in Tannaitic midrashim. It was included in the printed edition of the Mekhilta de-Rabbi Shimon bar Yohai but this portion of that composition is based on a medieval collection and is not found in any manuscript. 
hold that one's vessels must rest when they permit nearly all of the other activities discussed in the Mishnah, including those in the baraita! "Shevitat keilim" might be able to explain why Beit Hillel would prohibit grinding wheat in a water-mill, but only if we totally ignore Beit Hillel's overall approach to the issue. ${ }^{8}$ Furthermore, without any particular difficulty, the sugya later reverses this position, citing a statement by R. Oshaya in the name of R. Assi who limits the concept of shevitat keilim to Beit Shammai. It is not at all clear from the sugya whether this position opposes R. Yosef or simply clarifies his statement. Ultimately, the Bavli's presentation of the Amoraic explanations of the baraita creates the impression that Rava believes that Beit Hillel would prohibit using a water-mill because of the loud noise it makes while other Amoraim, certainly R. Oshaya in the name of R. Assi attributes the restriction on the water-mill to Beit Shammai because of shevitat keilim. ${ }^{9}$ Beit Hillel, who does not agree with such a general prohibition, would indeed allow one to put wheat into a watermill on erev Shabbat. The Bavli offers no explanation whatsoever as to why this is not an infringement on the prohibition of making a noise.

We should emphasize here that early literature agrees that it is prohibited to place wheat in a water-mill before Shabbat. This is stated anonymously in the Tosefta, is explained in three different fashions in the Yerushalmi, and is explained by Rava in the Bavli. No Amora ever waives this prohibition, at least not explicitly. In a reconstruction of this material that we offer in our book, we interpret R. Yosef as stating that Beit Shammai would prohibit the action due to their general mandate that one's vessels must rest on Shabbat. This does not, however, mean that R. Yosef would necessarily say that Beit Hillel permits. However, the construction of the sugya by the editors of the Bavli creates a direct dispute between Rava and R. Yosef. If one follows Rava, then placing wheat in a water-mill is prohibited because it makes noise. If one follows R. Yosef, who, according to the Stammaitic arrangement of his statement, attributes the baraita to Beit Shammai exclusively and not to Beit Hillel, then the action is permitted because we assume the halakhah does not follow Beit Shammai.

This sugya is thus another example as to how the Stammaitic editors create dialectical sugyot, passages in which Amoraim raise difficulties on one another, respond to each other's explanations of Tannaitic material, and seamlessly shift their dialogue from one topic to another. While their aims are primarily literary, such creations have significant impact on post-Talmudic halakhah. Halakhah

8 See Tosafot s.v. ולימא מר.

9 For a full analysis of the reconstruction of the sugya see Kulp and Rogoff, Reconstructing the Talmud: Volume II, ibid. 
can, at times, significantly shift without any sage actually having intended for such a shift to occur. Post-Talmudic halakhah is sometimes the result of literary processes of earlier editors, and not just of the legal decisions made by earlier halakhic authorities.

\section{Geonim}

The impact of the Bavli's construction of the sugya can already be seen in the Geonic period. R. Natronai Gaon, in a responsum concerning a Jew who leases his mill to a non-Jew, assumes that a Jew is permitted to set up a mill before Shabbat.

תשובות רב נטרונאי מאואן סימן נה וששאלתם: ישראל שיש לו רחים מחוץ לתחום ונותן אותם לגוי בקבלה, מהו שיטחן גוי בשבת?

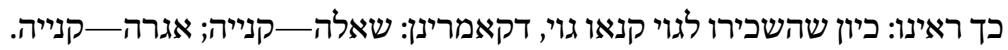

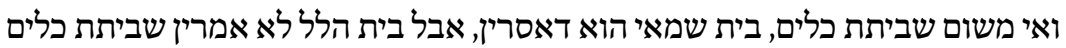
ולא אסרין, דקאמרינן: אבל אין נותנין חטים לרחים שלמים אלא אם כל כן שיטח הליאנו מבעוד

והא בריתא בית שמאי היא, דקאמרינן לקמן: השתא דאמר ר' אושעיא אמר רב אסי:

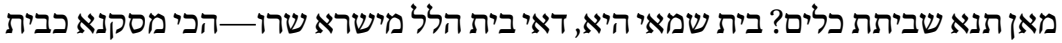

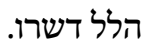

\section{Teshuvot of Rav Natronai Gaon no. $5^{810}$}

And that which you asked concerning a Jew who has a mill outside of the Shabbat border (tehum) and leases it to a gentile, may he [the gentile] use it for grinding on Shabbat?

Thus we have seen: Since he leased it to the gentile, the gentile has acquired it. As we say: borrowing — he acquires it; leasing — he acquires it. And if you say [there is the problem of] "resting of vessels," it is Beit Shammai who forbids. But Beit Hillel does not hold "resting of vessels" and does not prohibit, as we say: "But one may not place wheat in a watermill unless it can be ground when it is still day."

And that baraita is according to Beit Shammai, as we say further, "Now that R. Oshaya said in the name of R. Assi: Which Tanna [holds] the rest-

10 Text of responsum from Robert Brody, ed., Teshuvot Rav Natronai bar Hilai Gaon (Jerusalem: Makhon Ofeq, 2011). 
ing of vessels? It is Beit Shammai, for Beit Hillel permits"11 — this is the conclusion according to Beit Hillel who permits.

We will begin with an analysis of the question. M. 'Abod. Zar. 1:9 prohibits leasing a bathhouse to a gentile because it is referred to as belonging to the Jew. $b$. 'Abod. Zar. 21b cites a baraita (= t. 'Abod. Zar. 2:9) where R. Shimon b. Gamaliel explains that the prohibition exists because the gentile will operate the Jew's bathhouse on Shabbat. This will lead onlookers to think that either the Jew himself or the gentile at the behest of the Jew is performing forbidden labor on Shabbat. ${ }^{12}$ The questioner asks the Gaon whether it is permissible to lease a mill to a gentile outside of the town limits, a place where Jews would not be able to travel on Shabbat. ${ }^{13}$ The location of the mill removes the concern for marit ayin, the appearance that the Jew is doing work on Shabbat. ${ }^{14}$ This leaves the Gaon with the independent question of whether a Jew's vessels must rest on Shabbat.

R. Natronai Gaon begins by quoting a short piece of Talmud found on b. 'Abod. Zar. 15a. The statement, which is ultimately refuted at the end of the sugya, suggests that a gentile legally acquires whatever he borrows or leases from a Jew..$^{15}$ Therefore, there would be no prohibition preventing the gentile from using it on Shabbat. R. Natronai adds that since the vessel is leased and thus there is not a complete transfer of ownership, some might suggest that the gentile's use is prohibited because of "the resting of vessels." However, the mandate for "resting of vessels" is held only by Beit Shammai. Beit Hillel does not have such a halakhic category, and thus there is no problem with the Jew's

11 It is likely that R. Natronai has a version of the Bavli which explicitly states that Beit Hillel would permit. See ibid., 166 n. 1 .

12 See also responsum no. 59 about leasing a bathhouse that is not widely recognized as belonging to a Jew. See ibid., $166-167$.

13 The distinction between the ruling in and out of the town limits is based on b. Mo'ed Qat. 12a. We follow Brody who believes that the mention of the town limits was part of the original question. It is possible that $\mathrm{R}$. Natronai rules that mar'it ayin would not apply to a mill as it would a bathhouse, in which case his lenient ruling would be applicable in all cases. See Brody, ibid., n. 3 .

14 A similar question is asked about Jewish-Gentile partnerships. If a business and all of its assets are co-owned by a Jew and gentile how can the Jew be certain he will not benefit from the forbidden labor performed on Shabbat. The question is particularly relevant when the partners own a bathhouse, bakery, olive press, or mill. All are examples of fixed locations which would carry the name of the Jewish owner. There is less of a concern with movable property. See Joel Meuller, ed., Geoney Mizraḥ Uma'arav (New York: Mekhon Menora, 1959), no. 5 o.

15 This is true even if the gentile does not acquire the vessel according to the final halakhah. See Brody, Teshuvot, 165 n. 2. 
mill being used by a gentile on Shabbat. Note that R. Natronai is clearly following what seems to be the conclusion of the sugya-Beit Hillel does not prohibit the use of the water-mill. Beit Hillel is not the author of this baraita. R. Natronai does not even refer to Rava's explanation that putting wheat in the water-mill is prohibited due to the noise; he reads the sugya as rejecting Rava's reading of the baraita in favor of that of R. Yosef. He fully accepts R. Yosef's explanation of the prohibition as being due to "resting of vessels" as well as R. Oshaya's ascription of the Toseftan baraita to Beit Shammai. In sum, since the mill is found outside the town limits there is nothing to prohibit its use by the gentile on Shabbat.

\section{Rishonim}

In direct contrast to the geonic leniency, R. Hananel holds that Beit Hillel prohibits using the water-mill because it makes a noise and that we should rule in accordance with this opinion.

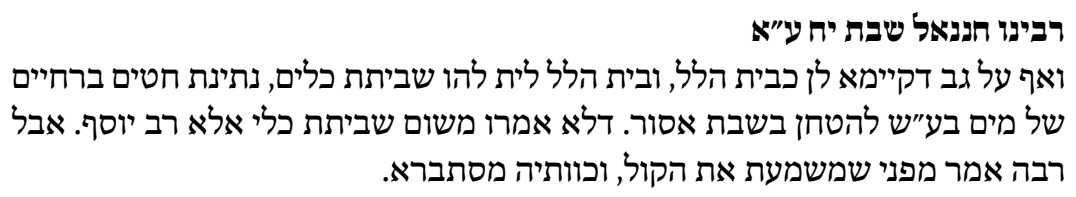

Rabbenu Ḥananel on b. Šabb. 18a

Even though we follow Beit Hillel, and Beit Hillel does not hold "resting of vessels," placing wheat in a water-mill on erev Shabbat in order to grind it on Shabbat is forbidden. For only R. Yosef said it is prohibited because of "resting of vessels." Rabbah said it is because it makes noise. And his logic is reasonable.

R. Hananel reads the sugya as a debate between R. Yosef and Rabbah concerning why it is prohibited to place wheat in a water-mill. Were we to explain that it is prohibited because of "the resting of vessels," then we would have to permit the action because only Beit Shammai rules this way. But R. Hananel insists that the halakhah follows Rabbah, ${ }^{16}$ probably due to the general preference for Rabbah over R. Yosef. ${ }^{17}$

16 Rif $6 \mathrm{a}-\mathrm{b}$ presents both explanations without making an explicit decision. He begins with the geonic position that Beit Hillel permits use of the water-mill and then adds "there are those who say it is forbidden because of noise." Both Ran and R. Zerachia HaLevi take this as an indication that the Rif himself is lenient.

17 See b. B. Bat. 114b. This is stated explicitly in Tosafot HaRosh b. Shabbat 18a. 
The Tosafists continue the debate over the appropriate halakhic ruling in light of the ambiguity of the sugya.

תוספות שבת יח עי"א והשתא אומר רבינותם: דהלכתא כרב יוסף, דמוקי ברייתא כב"ש דהא רב אושעיא קאי דיחי כוותיה. ולפי זה, ריחים מותרים דלדידיה לב"ה שרגים שרי אפיי היכא דקעביד מעשה ולא חייש להשמעת קול. ולי נראה, דרב אושעיא לא מוקי לה כב"ש, אלא הש"ס הוא דקאמר הכי: הא מני? ב"ש

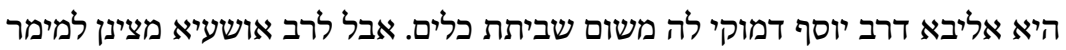

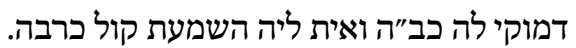

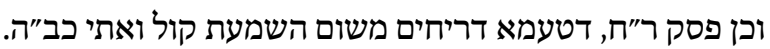

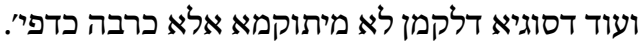

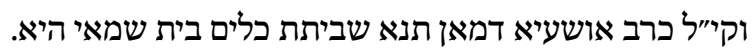

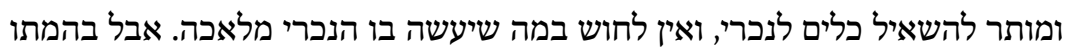
אסור להשאיל דשביתת בהמתו עליו דאורייתא. ומית.

\section{Tosafot b. Šabb. 18a s.v. Vehashta}

Rabbenu Tam rules that the law follows R. Yosef who attributes the baraita to Beit Shammai for R. Oshaya follows him. Therefore, use of a mill is permitted, for according to R. Yosef, Beit Hillel permits even if he performs an action, and he has no concern for making a noise.

However, it appears to me that R. Oshaya does not attribute the baraita to Beit Shammai. Rather, it is the anonymous voice who states: "who is this? It is Beit Shammai according to R. Yosef who says the problem is shevitat keilim."18 However, it is possible to say that R. Oshaya attributes it to Beit Hillel, and he holds [there is concern] of making a noise, as does Rabbah. This is also the ruling of R. Hananel: the reason for the [prohibition of the use of the] mill is because it makes a noise and this follows Beit Hillel. Furthermore, the sugya later on (19a) can only be understood according to Rabbah, as I have explained previously.

We do rule like R. Oshaya that the Tanna who holds of shevitat keilim is Beit Shammai.

18 The language of the Tosafot raises the possibility that there is a variant reading in the sugya which explicitly asks "who is this." The passage as presented in the Tosafot HaRosh ad. loc. clarifies that author of the Tosafot is simply rephrasing the Talmudic argument in his own words. 
It is permitted to lend vessels to a non-Jew, and there is no problem with what the non-Jew will do with them on Shabbat. But, one cannot lend an animal to a non-Jew because there is a Torah law requiring his animals to rest.

There are two voices in this passage, Rabbenu Tam and an anonymous collocutor, likely R. Samson of Sens. ${ }^{19}$ Rabbenu Tam rules according to R. Yosef because $R$. Yosef is supported by R. Oshaya, making this a case of two Amoraim against Rabbah, who remains a lone voice. To Rabbenu Tam the line in the Talmud that states, "Now, however, that R. Oshaya said in the name of R. Asi: Which Tanna [holds that] the resting of vessels is a biblical commandment? It is Beit Shammai" is not only a general remark of R. Oshaya concerning the dispute between the Houses. R. Oshaya is claiming that the Toseftan baraita should be attributed to Beit Shammai. Since we do not rule like Beit Shammai, the water-mill prohibition is waived.

The anonymous author of the Tosafot disagrees with Rabbenu Tam's reading of the sugya. He provides two pieces of support for ruling according to Rabbah that the water-mill is prohibited because it makes noise. First, he engages in a bit of Talmudic criticism to show that the sugya takes R. Oshaya's words out of context. R. Oshaya originally stated only that Beit Shammai mandates shevitat keilim and not Beit Hillel. R. Oshaya was not referring to the Toseftan baraita. Rather, he was referring to the midrashic baraita quoted earlier, "And in everything that I have said to you take heed' this includes the resting of vessels." This baraita should be ascribed to Beit Shammai and not Beit Hillel. While he does not state this explicitly, he may even have detected this from the phrase "from the Torah" which implies that R. Oshaya is referring to a source that reads shevitat keilim into the Torah-and that can only be the midrashic baraita. In contrast, the Toseftan baraita does not in any way imply that the prohibition is from the Torah. R. Oshaya clarifies that the midrashic baraita should be ascribed to Beit Shammai and not Beit Hillel. It is only the context of the sugya, where R. Oshaya's statement follows the debate between R. Yosef and Rabbah, that makes it seem as if R. Oshaya is siding with R. Yosef, who explains the prohibition as the result of shevitat keilim and not due to the problem of making noise. It is the editors who portray R. Oshaya as clarifying the Toseftan baraita, which he attributes only to Beit Shammai; they lead us to believe that Beit Hillel would allow putting wheat into the water-mill. This is an excellent example

19 The Tosafot on Shabbat found in our collection were compiled and edited by R. Eliezer (ben Solomon) of Touques based on the Tosafot of R. Samson of Sens. See Ephraim E. Urbach, Ba'aley HaTosafot (Jerusalem: Mossad Bialik, 1968), 470-474. 
of the sensitivity of the Tosafot to separating the editorial layer from the words of the Amoraim themselves. ${ }^{20}$ The anonymous Tosafist separates R. Oshaya's statement from its context in the sugya and arrives at his halakhic conclusion by focusing on the original intent of the Amoraic material.

The Tosafist further supports his halakhic ruling by arguing that another sugya accords with Rabbah. The sugya on 19a refers to m. Šabb. 1:9, "and both [houses] agree that one may lay olive press beams and wine rollers [on erev Shabbat]." The sugya explains that Beit Shammai concedes to Beit Hillel in this instance because even if one performed either of these activities on Shabbat itself one would not be liable for a hatat, a sin-offering, the punishment for a transgression of a biblical Shabbat prohibition. According to this sugya, Beit Shammai does not prohibit starting certain activities on erev Shabbat due to a general category of "resting of vessels." Rather, they prohibit beginning on erev Shabbat any activity which if done on Shabbat would cause one to be liable for a hatat. This understanding of Beit Shammai's position contradicts R. Yosef's explanation of their position, and thus implies that the explanation of the baraita on 18a should follow Rabbah and not R. Yosef.

An interesting modification to the interpretation of the sugya emerges in 13th-century France. Sefer HaTerumah and others append an explanation to the noise prohibition, one that we do not find prior to that point. ${ }^{21}$

\section{ספר התרומה הלכות שבת סימן רכ כליכ

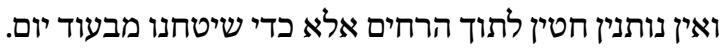

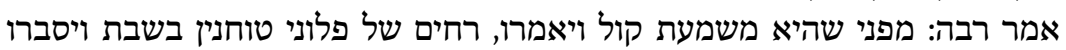
דבשבת נתנו החטים.

\section{Sefer HaTerumah, Hilkhot Shabbat No. 220}

One may not place wheat in a water-mill unless it can be ground when it is still day.

Rabbah said: because it makes a noise and they will say, "So-and-so's mill is grinding on Shabbat," and they will think that he placed the wheat on Shabbat. ${ }^{22}$

$20 \quad$ For more examples see Shamma Friedman, "Al Derekh Ḥeker Hasugya," Texts and Studies I, ed. H.Z. Dimitrovsky (New York: Jewish Theological Seminary, 1978), 288-296.

21 On R. Baruch b. Yitzhak, the author of Sefer HaTerumah, and his mistaken association with the city of Worms see Simha Emmanuel, "Biographical Data on R. Baruch b. Isaac," Tarbiz 69, no. 3 (200o): 423-440. 
Following the anonymous voice in the Tosafot, Sefer HaTerumah rules in accordance with Rabbah and against R. Yosef. Placing wheat in the water-mill is prohibited because it produces a noise. However, his explanation of the prohibition of making noise is quintessentially different from any other explanation we have yet encountered. Sefer HaTerumah explains that the concern of noise production is one of marit ayin, or perhaps we should say, marit ozen. Passersby will hear the grinding mill and assume that the owner has actively violated Shabbat by placing the wheat in the mill on Shabbat itself. This explanation differs dramatically from the original Amoraic material where the sound itself is the problem. A cacophonous sound such as that made by the water-mill will disrupt the intended Shabbat atmosphere.

We should note the similarity between the question posed to the Gaon and the ruling of Sefer HaTerumah. The questioner in the Geonic responsum is also concerned with what other people might think, and this is why he mentions that the water-mill is outside the Shabbat border. If it is inside the border, he assumes it would be prohibited lest people think that the Jew is using his watermill on Shabbat, just as the Talmud is concerned lest people think a bathhouse leased to a Gentile is being operated by a Jew (b. 'Abod Zar. 21a). This is the Talmudic source for the fear that people will confuse something being operated on Shabbat without a violation (because the Gentile is operating it) with something being operated on Shabbat in violation of the law (because the Jew is operating it). Sefer HaTerumah takes this concern and applies it to hearing a water-mill grinding on Shabbat. Unlike the other cases in the first chapter of $\mathrm{m}$. Šabb, where the work is being done silently (soaking of dyes, dyeing wool, setting traps), the water-mill is an audible process and will attract attention. This is why the noise causes it to be prohibited. Not because making noise on Shabbat is itself a problem.

What causes Sefer HaTerumah to change the interpretation of Rabbah's explanation? His explanation is not found in either Talmud. Nowhere in the Talmudim is it suggested that a permissible act, such as beginning a process on erev Shabbat, is prohibited because it makes a loud enough noise such that passersby may think that the Jew himself is working on Shabbat. It seems as if his innovative interpretation is a direct result of the Babylonian sages' limitation of the general prohibition against making loud noises on Shabbat. ${ }^{23}$

The primary sugya on the prohibition of making a noise on Shabbat is found on b. 'Erub. 104a: ${ }^{24}$

See Ethan Tucker, https://mechonhadar.s3.amazonaws.com/mh_torah_source_sheets/CJ LVInstruments.pdf 27 n. 43. 
בבלי עירובין קד עי"א

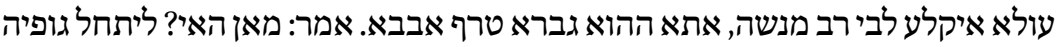

דקא מחיל ליה לשבתא. אמר ליה רבה: לא אסרו אלא קול של שת שיר.

\section{b. 'Erub. 104a}

Ulla was visiting R. Menashe's house. A man came by and knocked on the door. Ulla said: Who is that? May his body shudder (leithal) for having violated (maheil) Shabbat.

Rabbah said to him: They forbade only music.

Ulla, the Eretz Yisraeli Amora who would travel back and forth to Babylonia, is appalled by a knock he hears on the door while visiting Rav Menashe. Ulla reacts so viscerally because he believes, in line with the Eretz Yisraeli tradition, that producing a loud noise on Shabbat is strictly prohibited. Rabbah responds that the prohibition is limited to musical sounds. As the sugya continues, earlier rabbinic sources are brought which seem to contradict Rabbah's claim. The Stam succeeds in contextualizing each source in order to defend Rabbah's ruling. However, while the sugya does defend Rabbah against all difficulties, it ultimately offers no clear-cut statement of preference for Rabbah over Ulla. The lack of a clear ruling in the Talmud leads post-Talmudic authorities to debate whether loud noises or only music is prohibited on Shabbat.

Rabbenu Hananel argues that despite the resolutions to Rabbah's position, halakhah does not rely on strained resolutions and thus follows Ulla. He writes:

רבפו חפנאל עירובין קד עי"א ואע"ג דשני רבה כל הני תיובתא דמקשי עליה, אשינויי לא סמכינן ולא דחינן לשמועה דעולא.

\section{Rabbenu Hananel b. 'Erub. 104a}

Despite the fact that Rabbah deflected all the challenges brought against him, we do not rely on [strained] resolutions, and we do not reject Ulla's tradition.

This conclusion is consistent with his ruling in the case of the water-mill where he also prohibits the production of a loud non-musical noise. R. Yitzhak Alfasi

analysis see See Aviad Stollman, Commentary of Chapter Ten, Eruvin, 375-391 and Ethan Tucker, ibid. 
(Rif), however, argues that the law accords with Rabbah's limitation of the noise-prohibition to music:

ריי"ף עירובין לה עיב

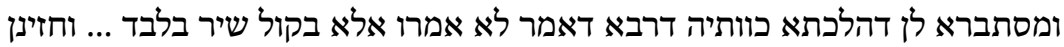

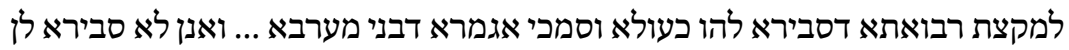

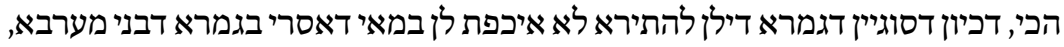

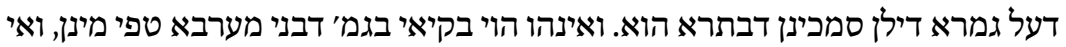

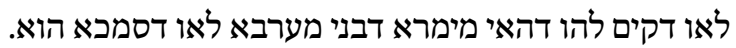

\section{R. Yitzhakak Alfasi b. 'Erub. 35b}

It makes sense to say that the halakhah follows Rava [= Rabbah], who said that only music is prohibited ... We have seen that some of the masters [like R. Hananel] hold like Ulla and they rely on the Talmud Yerushalmi ... But we do not hold this way; since the sugya of our [= Babylonian] Talmud is permissive, we don't care if the Talmud Yerushalmi forbids, because we rely on our Talmud, for it is later, and [its editors] were experts in the Talmud Yerushalmi more than we are. They would not have permitted here unless they knew that the statement from the Land of Israel was unreliable.

According to the Rif, the Bavli follows Rabbah, probably because he senses that the Stammaitic deflection of all difficulties reveals the "Bavli's" position. Unlike R. Hananel, the Rif is not concerned with the forced nature of these deflections. He is aware of the Yerushalmi's ruling that making any type of loud noise is prohibited, but argues that the law accords with the Bavli because it is later and it would have had the opportunity to reject the Yerushalmi. The Rif's position accords with what seems to be his lenient ruling on the water-mill. ${ }^{25}$ Thus, both the Rif and R. Hananel correlate their general position concerning noise on Shabbat with their particular position regarding the water-mill. To R. Hananel, all noise is prohibited, and thus the water-mill can be prohibited due to the noise. To the Rif, only music is prohibited, and the water-mill prohibition is ascribed to Beit Shammai, due to shevitat keilim.

Twice on b. Beșah 3 oa (s.v. אין מטפחין, and s.v. תנן אין מטפחין) the Tosafot imply that they accept Rabbah's limitation of the noise prohibition. First, they explain that one reason that clapping might be prohibited is that it is considered mak-

25 See above n. 16. 
ing music. Had it simply been noise, it would have been permitted. Later on the same page, cognizant of the fact that people in their community do not adhere to the Mishnaic prohibition of clapping, they justify their behavior:

\section{תוספות בייצה ל ע"א ד"ה תגן אבל לדין לדידן שרי, דדוקא בימיהן שהיו בקיאין לעשות כלי שיר שייך למגזר. אבל לדידן, אין אנו בקיאין לעשות כלי שיר ולא שייך למגזר.}

\section{Tosafot, b. Beșah 3oa, s.v. Tenan}

However, for us, these activities are permitted; for it was only in their time, when people had the skill to make musical instruments, was it necessary to decree [against clapping lest someone make a musical instrument]. But for us, we are not such experts that we know how to make musical instruments, and therefore there is no need for the decree.

According to the Tosafot, based on the Stam on b. Beșah 36a, the prohibition against clapping exists only in a situation where the people are skilled artisans who know how to fashion their own instruments. Absent this concern, clapping is permitted. Clearly, the Tosafot have no problem with the loud noise made by clapping itself, thus indicating that they rule according to Rabbah-only musical sounds are prohibited. ${ }^{26}$

Sefer HaTerumah was written by R. Baruch b. R. Yitzhak, a student of R. Yitzhak the Elder, one of the greatest of the Tosafists. Thus, Sefer HaTerumah is the first halakhic authority to combine the Tosafot's restrictive ruling on using a water-mill with their lenient view of the concern of making noise in general on Shabbat. To resolve this albeit minor crisis, Sefer HaTerumah reinterpreted the problem of the noise produced by the water-mill - the noise itself is not prohibited, it is the potential misunderstanding that it might cause. Note that there is no other possible reason available for him to prohibit putting the wheat in the water-mill on erev Shabbat, for this is the only reason that can accord with Beit Hillel. And since the water-mill sound is not music, it should seem to be permitted. To resolve all of these issues, he interprets the prohibition in the sugya in an innovative fashion: The noise will make outsiders think that the Jew is operating his mill on Shabbat. ${ }^{27}$

26 The Tur and Beit Yosef, ơ 338 explain that Rabbenu Tam also holds like Rabbah because he permits drawing water with a wheel which would make a noise loud enough to forbid according to those who follow Ulla.

$27 \quad$ R. Asher b. Yehiel questions the very nature of the prohibition because he finds no prece- 


\section{The Chime Clock: A Test Case}

The technological advancement of a verge escapement clock, which for the first time allowed a clock to ring hourly, brought 15th-century Ashkenazi halakhic authorities to revisit the case of a water-mill set in motion before Shabbat. These rabbis understood the two situations to be similar-both set in motion before Shabbat an instrument that will emit a noise on its own on Shabbat. And since Ashkenazim (with the exception of Rabbenu Tam) ruled that the water-mill was prohibited because it makes a noise (and not because of shevitat keilim), they needed to decide why such noise was prohibited, and whether it applied to the clock as well. In other words, their debate echoed the dispute between earlier Rishonim concerning the interpretation of Rabbah's statement, "because it makes a noise."

R. Jacob Weil cites what is certainly the original interpretation of Rabbah's statement concerning the water-mill, and thus prohibits using a chime clock.

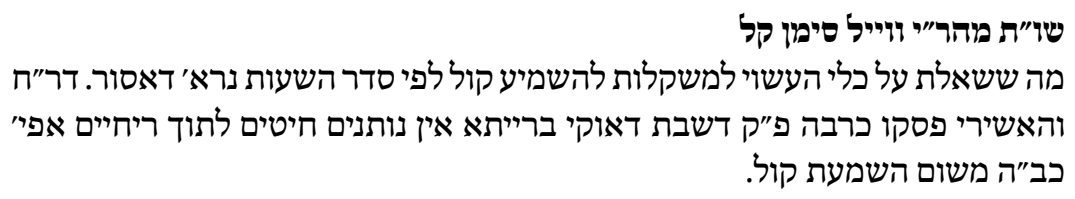

\section{R. Jacob Weil Responsum No. 130}

That which I was asked about a vessel made with weights to sound a chime on the hour, it seems that it is prohibited. For R. Hananel and R. Israel of Krems ruled according to Rabbah in the first chapter of Shabbat who explains that the baraita which prohibits placing wheat in the mill is even according to Beit Hillel because it makes noise.

R. Jacob Weil follows the ruling of R. Hananel and forbids performing any action that will make a regular noise on Shabbat because of the noise itself. This ruling remains consistent with the original meaning of the prohibition. A chime clock makes a loud noise much like the grinding of a water-mill that even Beit Hillel would prohibit.

R. Judah Landau, on the other hand, permits because he understands the noise prohibition in light of the interpretation innovated by Sefer HaTerumah.

dent for it. He describes it as "a poor reason ... an innovation which is not found anywhere." See Rosh on Šabb. 1:33. 
ספר האגור הלכות הזיעאת שבת סימן תקיט

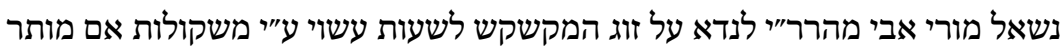

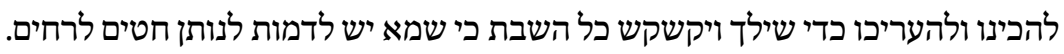

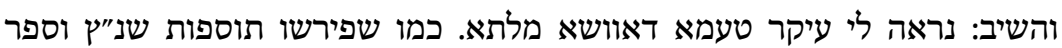

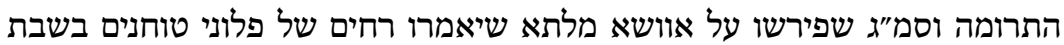

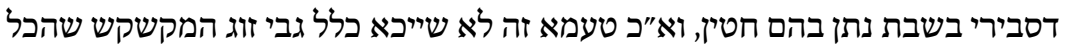

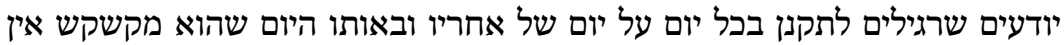

מתקנין אותו כלל.

\section{Sefer HaAgur, Hilkhot Hotsa'at Shabbat no. 519}

My father and teacher R. Judah Landau was asked about a bell which rings hourly through the use of weights, is it permitted to prepare and set it up so that it will ring on Shabbat, for perhaps we should compare it to placing wheat in the mill? And he answered: It seems to me that the main reason [to prohibit] is because the matter will be noticeable as was explained by the Tosafot Shantz, Sefer HaTerumah and Sefer Mitzvot Hagadol, who explained that "the matter will be noticeable" [as follows]: People will say that so-and-so's mill is grinding on Shabbat because they will think that he placed the wheat in it on Shabbat. If so, the reason is not relevant with regard to the bell which rings because everyone knows that they are normally set up the previous day to work on the following day and on the day it rings it is not set up at all.

According to R. Judah Landau the loud noise produced by the chime is not a direct violation of Shabbat. The chime, like the grinding mill, is not considered music and therefore is permitted. ${ }^{28}$ But unlike in the case of the mill, when it comes to the clock, the concern that passersby will think that a Jew violated Shabbat does not exist. Everyone knows that chime clocks are set up before Shabbat so there is no reason to forbid them on Shabbat. Note that R. Landau agrees with R. Jacob Weil that the law accords with Rabbah in that Beit Hillel would prohibit the use of the water-mill on Shabbat. Their disagreement over the halakhic ruling stems from their interpretation of that prohibition, i.e. if there is a problem with the noise itself or what people may think when they hear the noise.

28 Cf. Shulhan Arukh HaRav who describes the chime as musical sounds. 


\section{Shulhan Arukh}

R. Yosef Karo and R. Moshe Isserles (Rema), in their combined product of the Shulhan Arukh, reflect all of the different rulings that we have seen on this issue above:

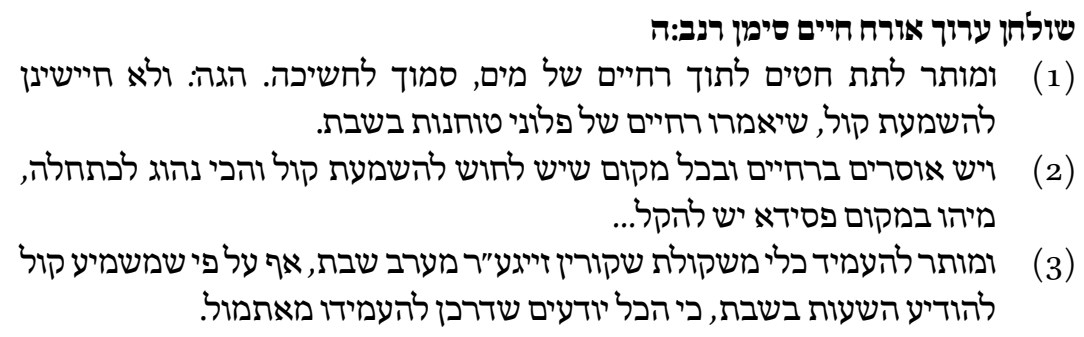

\section{Shulhanan Arukh, Oب̣ 252:5}

(1) And one may put wheat into a water-meal before dark. Note: and we are not concerned about making noise, that people will sayso-and-so's mill is grinding on Shabbat.

(2) And there are those who prohibit with a mill and in any situation where there is a concern of making noise. And this is the primary practice. However, in a case of loss one can be lenient ...

(3) And it permitted to set up a vessel with weights called a clock, on erev Shabbat, even though it makes a noise to announce the time on Shabbat, because everyone knows that it is set up the previous day.

R. Yosef Karo rules that one is permitted to place wheat into a water-mill on erev Shabbat. In the Beit Yosef, he explains that his ruling follows Rabbenu Tam, the Rif, and Rambam who all rule according to R. Yosef, who they read as attributing the baraita to Beit Shammai. Since halakhah follows Beit Hillel, the prohibition is waived. ${ }^{29}$ In section one, R. Moshe Isserles opens by noting that if we rule according to R. Yosef, we must say that the noise that the water-mill makes is not a problem. The Rema then must explain why it is not a problem. His explanation as to why this is not a concern demonstrates that he understands the noise problem in the same way as Sefer HaTerumah and R. Judah Landau do. Isserles imagines that the reason to prohibit could

29 Neither the Rif nor the Rambam explicitly permit. He explains that the Rif follows the permissive opinion which he cites first and that Maimonides permits because he rules that there is no concern for the resting of vessels (Šabb. 6:16) and makes no mention of the case of the water-mill in the Mishneh Torah. 
only be that others would suspect the owner of a Shabbat violation. R. Yosef, who rejects Rabbah, must therefore not have had such a concern. We should emphasize the radical transformation occurring here in the interpretation of R. Yosef. In the original sugya, and essentially through the Tosafot, there was no real explanation as to why R. Yosef rejected Rabbah. He strangely just says, "why not say [putting wheat in the water-mill] is prohibited because of shevitat keilim." He does not add in any rejection of Rabbah. Indeed, this is one of the essential difficulties in the sugya. Paradoxically, what was originally offered by Sefer HaTerumah as an explanation for Rabbah in order to rule according to him despite the fact that making noise was considered permitted (and only song prohibited), here ultimately solves the conundrum as to why R. Yosef the Amora rejected Rabbah. R. Yosef rejected Rabbah because the former is simply not worried that the noise created by the water-mill will make people think that the mill was operated by a Jew on Shabbat. The earlier prohibition of making a noise was absolute; but its later understanding, connecting it with mar'it ayin, is subjective and can more easily be waived. This is an excellent example of the timelessness of classical Talmudic interpretation. An interpretation that arises in the thirteenth-century (Sefer HaTerumah) is seamlessly used to explain the statement of a fourth-century rabbi.

In section two, Isserles proceeds to rule against Karo and maintains that it is indeed prohibited to set up a water-mill before Shabbat or in any situation where a sound might lead one to think a violation of Shabbat is taking place. This too is, of course, a result of his following the reasoning of Sefer HaTerumah. Finally, in section three, Isserles again relates to the subjective nature of marit ayin. Despite the fact that the chime clock emits a noise (and a musical one at that), since there is no concern that a passerby may think there is a Shabbat violation, there is no reason to rule stringently. By this point, the Talmudic conversation has been thoroughly shifted into a question of mar'it ayin. The noise itself is never a problem, the only question is whether the noise will attract attention and lead people to think that a prohibited labor has been performed on Shabbat.

\section{Modern Halakhic Rulings}

Modern halakhic authorities have used the case of the water-mill as a reference point in discussing automated electronic devices set up ahead of Shabbat to operate on Shabbat. Despite the fact that modern Jews rarely encounter water-mills (except on trips to Neot Kedumim) modern devices can easily be set to emit noises on Shabbat. In our analysis below we address two prominent 
examples: the microphone and the radio. We will see how, in light of R. Moshe Isserles, the focus of the contemporary halakhic authorities has shifted entirely from the problem of the noise itself to a debate over the applicability of mar'it ayin.

R. Moshe Feinstein (d. 1986) refers to the noise prohibition in his discussion of the use of a microphone set up before Shabbat:

אגרות משה אזרח חיים חלק ג שימן נה א.... בחול אין הדרך להעמיד אותו בזממן הקודם הרבה להדבור מור, שלכן אסור בשבת

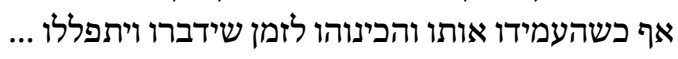

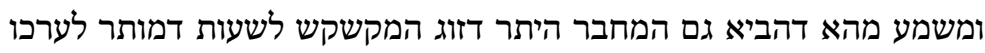

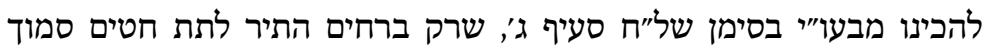

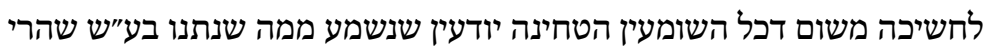

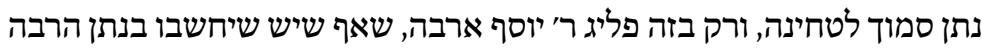

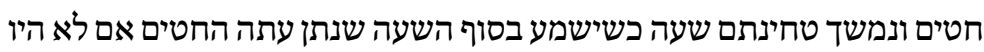

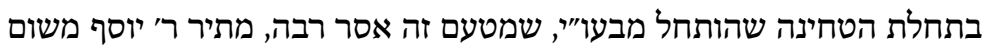

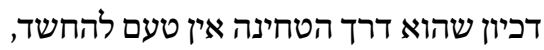
אבל בהשמעת קול כה"ג דנשמע גם החין התתחלה לחשר בשבת ואין הדרך כלל להעמיד

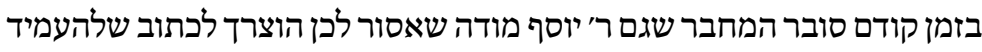

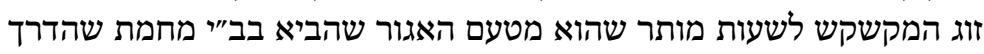
לתקנו בכל יום על יום שלאחריו.

\section{Iggrot Moshe o}

(1) It is not common on a weekday to set it [the microphone] up long before use and therefore it is prohibited [for use] on Shabbat even if it was set up and prepared before the time when they will speak and pray ...

(2) And it seems from the fact that the author [of the Shulhan Arukh] also cited the leniency to allow the use of a chime which rings hourly if it was set up before dark (338:3), that he permits placing wheat [into the mill] only close to dusk because anyone who hears the grinding knows that they are hearing what was placed before Shabbat for he put the wheat in place immediately before grinding. It is only in such a case that R. Yosef disagrees with Rabbah. For Rabbah prohibits in a case where one places a lot of wheat in the mill and it grinds for a long time if someone was not there when the grinding began before Shabbat because they will hear the grinding on Shabbat and think it was just placed there just now. R. Yosef permits since it is usual to place the wheat in the mill immediately beforehand there is no reason to be suspicious. 
(3) But making noise in this manner [with a microphone] which is heard for the first time on Shabbat and it is not customary to set it up beforehand; the author [of the Shulhan Arukh] believes that even R. Yosef would concede that it is prohibited. That is why he needed to write that setting up a chime which rings hourly is permitted based on the reasoning of the Agur cited by the Beit Yosef, which is that it is set up daily for the subsequent day.

In section one, R. Feinstein forbids using a microphone on Shabbat, because of Rabbah's prohibition of the water-mill as explained by the Rema. ${ }^{30}$ In section two, he addresses the two issues brought up in the Shulhan Arukh, the water-mill and the chime clock, and interprets the dispute between Rabbah and R. Yosef as hinging on the difference between the two. Chime clocks, he argues, are always set up the day before, and therefore, no one will think that the process was set up on Shabbat. Rabbah and R. Yosef disagree only concerning the water-mill. R. Yosef thinks that people will know that it is common to set up such a process well in advance, and therefore they will not believe that forbidden labor was performed on Shabbat. Rabbah disagrees and is concerned that people will think that the process was set up on Shabbat. We should note how seamlessly R. Feinstein integrates the medieval interpretation of the prohibition into the Amoraic debate fashioned by the editors of the sugya. To him, the debate is simply a question of the applicability of mar'it ayin. As we have said before, issues of marit ayin are inherently subjective. They are also more flexible and each particular situation can be judged differently. This differs, as we have stated, from the original two rabbinic justifications-shevitat keilim and making a noise, which were less flexible and more principled. With this interpretation in mind, when it comes to the microphone, people do not normally set it up the day before. Therefore, when a passerby sees or hears the microphone in use they will assume it was set up on Shabbat. ${ }^{31}$ In such a case even R. Yosef would prohibit (assuming that he rules against the "shevitat keilim" baraita, which he attributes to Beit Shammai). This is a significant step for R. Feinstein, for while we have a dispute concerning the water-mill (between Amoraim and Rishonim) and even a dispute concerning the chime clock (among Aharonim) over the microphone he posits that no one would disagree. This ability to posit a uniform stringency on this situation is a direct result of the transformation wrought by Sefer HaTerumah. Once the dispute

30 In this responsum he provides four reasons to prohibit. We deal here only with one of those reasons.

31 Tzitz Eliezer 4:26 makes a similar argument. 
becomes completely over mar'it ayin, a halakhic authority is essentially free to judge each situation as he or she sees fit, based on whether they believe mar'it ayin is potentially a problem. ${ }^{32}$ We should note that $\mathrm{R}$. Feinstein's thinking is also reflected in another of his responsa (Oㅂ 4:84) wherein he prohibits the use of a radio or television on Shabbat that was turned on before Shabbat.

In stark contrast to R. Feinstein's consistently stringent rulings on the use of electronic devices set up before Shabbat, R. Mordechai Yaakov Breish (d. 1973) offered a lengthy argument theoretically permitting setting up a radio before Shabbat to broadcast music or news on Shabbat for a person who is merely ill and not in mortal danger. The starting point for his ruling is found in R. Moshe Isserles' formulation of the prohibition: "And there are those who prohibit with a mill and in any situation where there is a concern of making noise. And this is the primary practice. However, in a case of loss one can be lenient." According to R. Breish, the Rema's words "in a case of loss one can be lenient," indicates that according to the letter of the law the act is permitted.

חלקת יעקב אורח חיים סימן סג

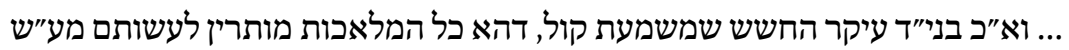

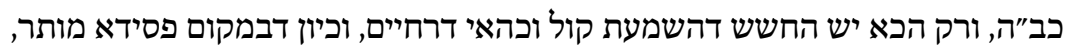

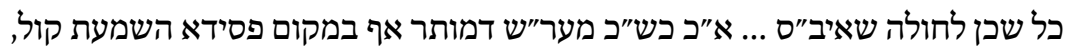

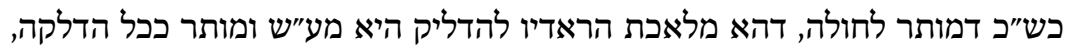

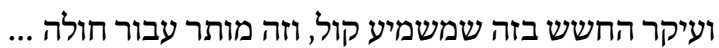

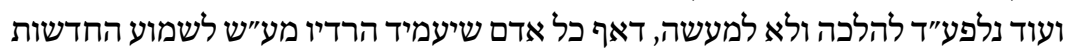

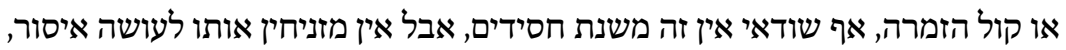

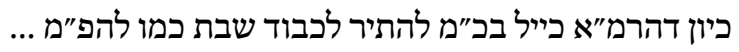

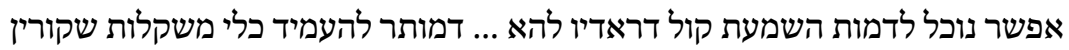

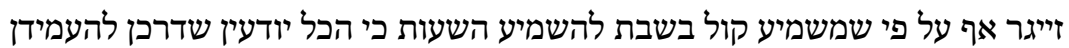

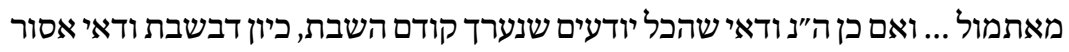

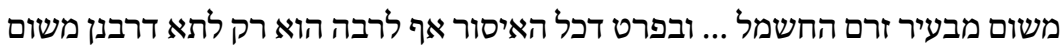

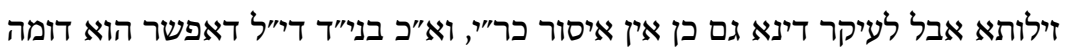

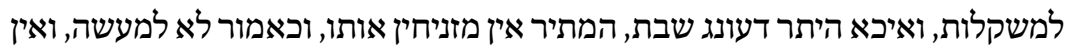

לאומרו בפרהסיי.

\section{Helkat Yaakov ọ̣ no. 63}

Therefore, in our case where the main concern is making a noise, because all labors are permitted to be set in motion before Shabbat according to Beit Hillel, and it is only here that there is a concern for making noise, as 
is true in the case of the water-mill, since it (making noise) is permitted in a case of loss, all the more so [it is permitted] in a case of a sick person who is not in mortal danger ... If this is correct, all the more so when it is permitted to set it up on erev Shabbat where making noise is permitted in the case of a loss and all the more so that it is permitted for a sick person. The use of a radio is prohibited because it is considered lighting a flame which is permitted if done before Shabbat like all other acts of burning, and the main concern is making a noise which is permitted for a sick person. ${ }^{33}$

Furthermore, in my humble opinion, according to the law and not in practice, any person who sets up a radio to broadcast the news or music, although it certainly is not pious behavior, should not be disparaged as one who transgresses, since R. Moshe Isserles permitted in all cases of "honoring the Shabbat" as he does in the case of incurring a loss ...

We can compare the radio to the chime clock which is permitted because everyone knows that it was set up yesterday [before Shabbat] ... The same is true in our case, where everyone knows that it was set up before Shabbat because electricity is forbidden [on Shabbat] due to burning. This is especially true because the entire prohibition even according to Rabbah is only a rabbinic prohibition due to the debasement [of Shabbat] but according to the letter of the law there is no prohibition as Rav Yosef ruled. Therefore, in our case where one can say that it is similar to the chime clock, and there is the permissive ruling of the "enjoyment of Shabbat," we do not disparage one who permits, and as was said, this is not meant to be a permissive ruling and it should not be stated in public ...

In brief, R. Breish posits that even according to the Rema, who expresses concern for making noise on Shabbat, one can set up a radio before Shabbat to operate on Shabbat. There is no question that this is true in the case of an ill person, for whom we can be lenient because the entire prohibition of making a noise is only rabbinic in origin, but it may even be theoretically permissible for everyone because the radio is analogous to the chime clock. Remarkably, in an observation we can assume was true for the community in which he lived, he argues that there is no concern for mar'it ayin because everyone knows that the

33 R. Breish understands there to be a total prohibition on actively using electricity on Shabbat because of the prohibited labor of burning. See Daniel Nevins, "The Use of Electrical and Electronic Devices on Shabbat," https:/www.rabbinicalassembly.org/sites/default/ files/public/halakhah/teshuvot/2011-2020/electrical-electronic-devices-shabbat.pdf, 2226. 
use of electricity is a violation of Shabbat and anyone who hears the radio on Shabbat will assume that it was set up before Shabbat. Note that this assumption which serves as the foundation of R. Breish's leniency is the exact opposite of R. Feinstein who argues that anyone who hears the microphone or radio in use on Shabbat will assume that it was set up on Shabbat. ${ }^{34}$

R. Feinstein and R. Breish, both Ashkenazi authorities, engage with the ruling of the Rema in their responsa. R. Feinstein relies on the Rema's concern for mar'it ayin in order to rule stringently in all cases. R. Breish posits that the Rema's concern is not applicable in the case of a radio that was set up before Shabbat.

Using the prohibition of the water-mill as the basis to prohibit setting up microphones and radios was not available to Sephardi poseqim. The Shulhan Arukh rules according to R. Yosef, who attributes the prohibition of using the water wheel to Beit Shammai and, by deduction, does not believe that setting up a process before Shabbat that will make a noise on Shabbat is prohibited at all. He simply does not seem to be worried about mar'it ayin. By extension, we could assume that setting up automated devices before Shabbat would also not seem to entail any problem of mar'it ayin. Thus, modern Sephardi authorities do not have available to them the precedent of the water-mill or the chime clock to prohibit the use of electronic devices on Shabbat that were set up before Shabbat. This issue is best articulated in the writings of R. Ovadiah Yosef (d. 2013) and his son R. Yitzhak Yosef.

R. Yitzhak Yosef was sent the following question after the publishing of the first edition of Yalkut Yosef, a digest of his father's halakhic rulings. The question concerns turning on a radio before Shabbat.

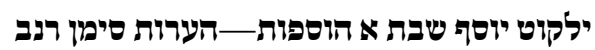

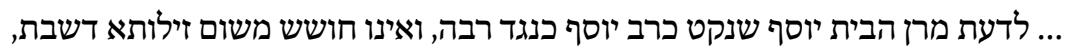

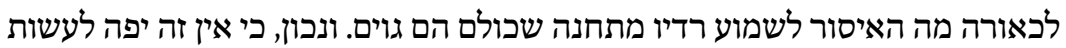

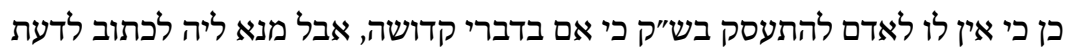
מרן הבית יוסף בלשון אסור ל...

34 R. Breish wrote the above responsum in September of 1939. In responsum no. 124, dated August 1965, R. Breish explains that he regretted issuing his earlier ruling and had since reversed his position. He forbids the use of all electronic devices apart from "opening a refrigerator door when the motor is operating," out of fear that the unlearned would intuit that all use of electronic devices is permitted on Shabbat. 


\section{Yalkut Yosef Shabbat I Notes no. $25^{2}$}

According to the Beit Yosef who follows R. Yosef against Rabbah, and has no concern for the debasement of Shabbat, what prohibition can there be against listening to a radio [on Shabbat] from a station that is entirely [operated by] gentiles. Granted, it is not appropriate to do so because a person should only engage with holy matters on Shabbat but on what basis can you write that our master, the Beit Yosef, prohibits ...

In his response to the question, R. Yitzhak Yosef concedes the point and yet searches for language to prohibit:

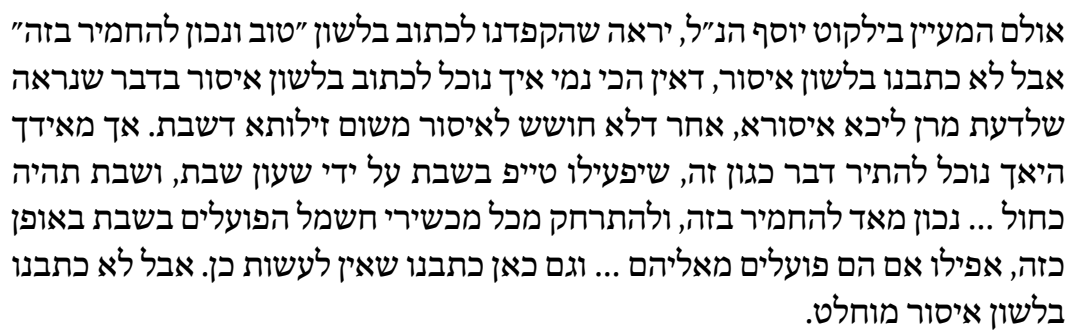

One who examines the aforementioned passage in the Yalkut Yosef will see that we were careful to write "it is correct and appropriate to be stringent in this matter" but we did not write that it was prohibited. For indeed, how could we use the language of prohibition in a matter in which our master [R. Yosef Karo] did not prohibit because he is not concerned to prohibit this because it is debasement of Shabbat. On the other hand, how can we permit an action such as this, i.e. setting up a timer to play a cassette tape on Shabbat, thereby turning Shabbat into a weekday ... It is very appropriate to be stringent in this matter, and to distance oneself from electronic appliances that operate on Shabbat in this manner, even if they operate automatically ... and here too we wrote it is not appropriate to do so. But we did not use the language of absolute prohibition.

R. Yitzhak Yosef cannot ascribe to R. Yosef Karo an absolute prohibition in the case of setting up a radio or cassette player before Shabbat to operate on Shabbat. After all, R. Yosef Karo ruled that setting up the water-mill before Shabbat was permitted, thereby rejecting the applicability of the prohibition of making noise to a process set up before Shabbat. R. Yitzhak Yosef cannot issue an outright prohibition. Therefore, he relies on the broader and vaguer category of "not turning Shabbat into a weekday" in order to strongly discourage the action without using language that implies explicit prohibition. We should note that 
R. Yitzhak Yosef, of course, is well aware that according to his father, if the prohibition was biblical (if performed on Shabbat), even R. Yosef Karo would agree that setting up the process before Shabbat is prohibited (as we shall see below). Here he is directly addressing the concern of his questioner that R. Yosef Karo never explicitly prohibits setting up a process that will make noise on Shabbat.

R. Ovadiah Yosef, in his responsum on the use of a radio that was turned on before Shabbat, argues that even R. Yosef Karo would explicitly prohibit in such a case.

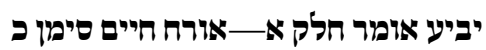
יש עוד טעם לאסור משום דאוושא מילתא והויא זילותא דשבת, וצריך לחוש למראית

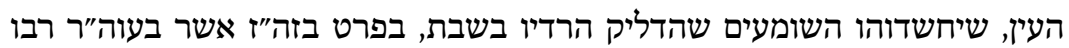

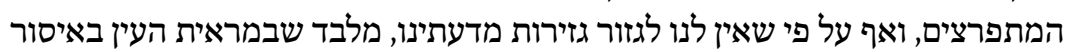

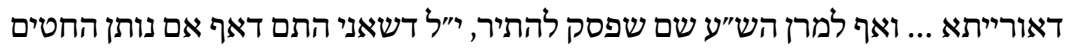

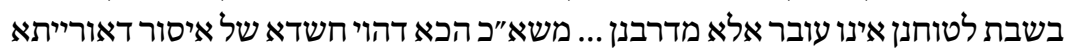

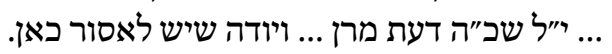

\section{Yabia Omer-Oफ̣ 1:20}

There is another reason to prohibit, which is that it makes noise and is a debasement of Shabbat, and one must be concerned because of mar'it ayin, that those who hear it will suspect that he turned on the radio on Shabbat, especially in our day wherein, due to our many transgressions there are a great number of violators of Shabbat [prohibitions], and although we may no longer make our own decrees, there is an exception with mar'it ayin of a Torah prohibition ... and even though our master the [author of] the Shulhan Arukh ruled to permit (in the case of the watermill), it should be said that such a case is different because even if he places the wheat in the mill to be ground on Shabbat he violates only a rabbinic prohibition ... which is not true here (in the case of the radio) where there is a suspicion of a Torah prohibition ... It should be stated that this is the position of our master [R. Yosef Karo] ... and he would agree to forbid in this case.

R. Ovadiah Yosef cannot easily prohibit the radio due to his strict adherence to the rulings of R. Yosef Karo who, in the Shulhan Arukh, allows placing wheat in the water-mill and seems unconcerned about the intendant mar'it ayin. ${ }^{35}$ How-

35 On R. Ovadiah Yosef's strict adherence to the rulings of R. Yosef Karo see Benjamin Lau, From 'Maran' to 'Maran': The Halakhic Philosophy of Rav Ovadia Yosef [in Hebrew] (Tel Aviv: Yedioth Ahronoth, 2005), 223-265. 
ever, he still posits that even R. Yosef Karo would explicitly prohibit turning on a radio before Shabbat for use on Shabbat. He distinguishes between the case of the water-mill which he classifies as a rabbinic prohibition if performed on Shabbat and turning on the radio which involves a Torah prohibition due to the use of electricity. In such a case, even R. Yosef Karo would be concerned about mar'it ayin. R. Ovadiah Yosef's desire to explicitly prohibit such an action forces him to unhinge the issue of the use of the radio from its Talmudic precedent, the water-mill. All rabbis, R. Yosef, and Rabbah, and their corresponding successors, R. Yosef Karo and R. Moses Isserles, would agree that if the process set in motion before Shabbat performs an action which can be misconstrued as being a Torah violation of Shabbat, that process is prohibited.

\section{Conclusion}

Modern halakhic authorities have been deeply concerned over the use on Shabbat of electronic devices set up before Shabbat. While most have reluctantly allowed the use of Shabbat timers to turn off and on lights, ${ }^{36}$ itself seemingly quite in line with the notion that Beit Hillel does not demand "shevitat keilim," when it comes to the use of microphones, radios, televisions, and other such devices, they invoke the prohibition of making noise, understood as being a result of the attention such devices attract, a problem of mar'it ayin. They are also clearly motivated by a general concern for the debasement of Shabbat. If all electronic devices are permitted for use on Shabbat as long as they were programmed beforehand, how would Shabbat be distinguishable from a weekday? Our Jubilee honoree, Rabbi Joel Roth, has articulated the force of this concern in his instructive article, "Melakhah U'Shevut: A Theoretical Framework." He writes:

While it is clear that the prohibition of excessively and unnecessarily exertive activities enhances the rest of Shabbat, it is also clear that their prohibition alone is insufficient to guarantee the restful spirit of Shabbat. There are so many things that one could do which would be neither melakhot nor overly exertive but would surely turn the unique Shabbat almost into a weekday. The other categories of shevut-prohibitions provide a reasonable response to the problem. They link the positive commandment that mandates rest with the negative commandment that

$36 \quad$ See for example Iggrot Moshe ọ̣ 4:6o. 
prohibits melakhah. Shevut-prohibitions of the resemblance, habit and conducive types link the prescriptive and the proscriptive elements of Shabbat. They provide further necessary safeguards against turning Shabbat into a weekday. ${ }^{37}$

Shevut, the prohibition of performing any act on Shabbat which violates the "spirit of Shabbat," is flexible in its application in much the same way that mar'it ayin is inherently flexible and subjective. Rabbi Roth is concerned that the "unique Shabbat" would be turned into "a weekday," a concern that clearly lies behind the reasoning of those halakhic authorities who prohibited setting up automated devices before Shabbat. While no violation of melakhah takes place if the process is set up before Shabbat, halakhic authorities are clearly concerned not only with technicalities but with outcomes as well. Despite the fact that the category of shevut exists to prohibit such cases where there is no performance of melakhah but a violation of the "spirit of Shabbat," contemporary poseqim preferred to prohibit setting up electronic devices before Shabbat on the grounds of mar'it ayin, a secondary concern. It seems that in their minds, if they were to invoke the category of shevut such for actions, although not melakhot, they would be considered a direct violation of Shabbat. Instead, they are prohibited because of a concern that others might think one is violating Shabbat. This choice of contemporary poseqim stems both from the language of the debate codified by the Rema and the larger concern of "not creating new decrees." ${ }^{38}$ The latter concern, referred to by R. Breish and many of the responsa on the use of electronic devices on Shabbat, prevents a contemporary poseq from adding new actions into the category of shevut prohibitions because they do not appear in classical rabbinic literature.

In response to the restrictive application of the shevut prohibition Rabbi Roth writes:

... it is ... absurd to refrain from promulgating shevut prohibitions for behaviors which might now be judged either to resemble or to be linked by habit, or to be linked by conduction to melakhot on the ground that earlier ages did not do so. ${ }^{39}$

37 Joel Roth, "Melakhah U'Shevut: A Theoretical Framework," Conservative Judaism 35, no. 3 (1982): 25-26.

38 See Shimon Levi, "Ein Gozrin Gzerot Ḥadashot Aḥar Hatimat HaTalmud," Shmatin 158 (2005): $65-83$.

39 Ibid., 27. 
Thus, in contrast to more conservative poseqim, Rabbi Roth argues for the revival of the category of shevut as grounds for prohibiting actions on Shabbat which cannot strictly be considered melakhah. This case thus provides an interesting distinction between the halakhic mindset of a leading authority in the Conservative movement and his counterparts in the Orthodox world. The former is willing to be more innovative in his application of an ancient concept, shevut, that Orthodox rabbis refrained from invoking. He is also more "traditional," in a sense, in that he does not invoke the category of mar'it ayin, a notion never connected in the Talmud to setting up a process that will begin before Shabbat and continue on Shabbat. Together, his invocation of shevut and his rejection of mar'it ayin (in these types of case) would provide Rabbi Roth, we can assume, with a possibility not open to many of his Orthodox counterparts. To allow setting up a microphone before Shabbat to operate in a synagogue on Shabbat, a move that will only enhance the Shabbat experience for synagogue attendees, but to prohibit turning on a radio or television before Shabbat and allowing it to operate all of Shabbat, a clear violation of the religious spirit of the day.

\section{Bibliography}

Bernstein, Louis. "The Emergence of the English Speaking Orthodox Rabbinate." Ph.D. dissertation, Yeshiva University, 1977.

Brody, Robert, ed. Teshuvot Rav Natronai bar Hilai Gaon. Jerusalem: Makhon Ofeq, 2011. Emmanuel, Simha. "Biographical Data on R. Baruch b. Isaac." Tarbiz 69, no. 3 (20oo): 423-440.

Friedman, Shamma. "Al Derekh Heker Hasugya." In Texts and Studies I. Edited by H.Z. Dimitrovsky, 288-296. New York: Jewish Theological Seminary, 1978.

Friedman, Shamma. "Orthography of the Names Rabbah and Rava." Sinai 110 (1992): 140-164.

Goldberg, Avraham. Commentary of Mishnah Eruvin. Jerusalem: Magnes, 1986.

Kulp, Joshua, and Jason Rogoff. Reconstructing the Talmud. 2nd ed. New York: Hadar, 2016.

Kulp, Joshua, and Jason Rogoff. Reconstructing the Talmud: Volume II. New York: Hadar, 2019 .

Lau, Benjamin. From 'Maran' to 'Maran': The Halakhic Philosophy of Rav Ovadia Yosef [in Hebrew]. Tel Aviv: Yedioth Ahronoth, 2005.

Levi, Shimon. "Ein Gozrin Gzerot Hadashot Ahar Hatimat HaTalmud." Shmatin 158 (2005): $65-83$.

Meuller, Joel, ed. Geoney Mizrah Uma’arav. New York: Mekhon Menora, 1959. 
Nevins, Daniel. "The Use of Electrical and Electronic Devices on Shabbat." Online: https://www.rabbinicalassembly.org/sites/default/files/public/halakhah/teshuvot/ 2011-2020/electrical-electronic-devices-shabbat.pdf.

Roth, Joel. "Melakhah U'Shevut: A Theoretical Framework." Conservative Judaism 35, no. 3 (1982): $25^{-26}$.

Tucker, Ethan. "The Stammaitic Impact on Halakhah: Two Sanctifications, Two Cups of Wine." In Reconstructing the Talmud. Edited by Joshua Kulp and Jason Rogoff. 149170. 2nd ed. New York: Hadar, 2016.

Urbach, Ephraim E. Ba'aley HaTosafot. Jerusalem: Mossad Bialik, 1968. 